\begin{tabular}{|l|l|l|l|}
\hline $\begin{array}{l}\text { Eiszeitalter und Gegenwart } \\
\text { Quaternary Science Journal }\end{array}$ & 57/3-4 & 253-260 & Hannover 2008 \\
\hline
\end{tabular}

\title{
Preface: The Heidelberg Basin Drilling Project
}

\author{
Gerald Gabriel, Dietrich Ellwanger, Christian Hoselmann \& Michael Weidenfeller
}

Since Late Pliocene / Early Pleistocene, the River Rhine, as one of the largest European rivers, has acted as the only drainage system that connected the Alps with Northern Europe, especially the North Sea. Along its course from the Alps to the English Channel the river passes several geomorphological and geological units, of which the Upper Rhine Graben acts as the major sediment trap (Fig. 1). Whereas the potential of sediment preservation of the alpine foreland basins is low due to the high dynamics of the system, and the area of deposition close to the North Sea was significantly affected several times by Pleistocene sea level changes, the ongoing subsidence of the Upper Rhine Graben offers a unique potential for a continuous sediment accumulation and preservation. The two major sediment traps are the Geiswasser Basin to the south and the Heidelberg Basin farther to the north. Generally the mean grain size of the deposited alpine sediments in the Upper Rhine Graben decreases from south to north. In the Upper Rhine Graben, the Heidelberg Basin acts as the distal sediment trap for alpine sediments transported northwards by the River Rhine. Here, continuous sediment deposition is less disturbed by significant unconformities than in the south. Therefore, the Heidelberg Basin defines a key location to understand the glacial evolution of the Alps since Late Pliocene, and moreover to compare it with that of Northern Europe (ELLWANGER et al. 2005).

The Heidelberg Basin hosts one of the thickest successions of Plio-/Pleistocene sediments in continental Mid-Europe. The Radium Sol Therme borecore drilled during 1913-1918, is located in the centre of the city of Heidelberg, close to the River Neckar. It is controversially discussed in literature. „Base Quaternary“ was interpreted to be at depths of $382 \mathrm{~m}$ (BARTZ 1951), $400 \mathrm{~m}$ (SALOMon 1927), or even $650 \mathrm{~m}$
(Fezer 1997). Nowadays, from extensive reflection seismics, it is well known that Quaternary deposits are thicker than $300 \mathrm{~m}$. Nevertheless, because reflection seismic surveys were only conducted in the vicinity of Heidelberg but not within the city itself, no detailed information about Quaternary structures has been available for this specific area up to now.

Aiming to better understand the geological evolution of the Heidelberg Basin, its control by climate changes and tectonics, and the correlation of alpine and north European glacial evolution, the Heidelberg Basin Drilling Project was promoted by the Leibniz Institute for Applied Geophysics (LIAG - formerly Leibniz Institute for Applied Geosciences, GGA-Institute) and the three Geological Surveys of Baden-Württemberg, Hessen, and Rheinland-Pfalz. The project focuses on the evolution of the basin since Late Pliocene. Investigations are mainly based on newly cored boreholes at three different locations within the Heidelberg Basin, which represent different types of the basin facies (Fig. 2). Two $300 \mathrm{~m}$ deep, cored boreholes in the city of Ludwigshafen - finished in 2002 and 2006 - represent the western margin of the basin. These boreholes were carried out within the framework of groundwater exploration and then left to the Geological Survey of RheinlandPfalz. The $350 \mathrm{~m}$ deep, cored borehole close to the village of Viernheim should reveal information about the central basin facies. This borehole was carried out and sponsored by the Geological Survey of Hessen and finished in summer 2006. The last of the cored boreholes, the borehole Heidelberg UniNord, is located above the depocentre of the basin, on the eastern margin of the Rhine Graben. This borehole reached its final depth of $500 \mathrm{~m}$ in July 2008 and obtained financial support from the Leibniz Institute for Ap- 
Fig. 1: The Heidelberg Basin (HDB) within the Geosystem "Rhine“ (modified after ELLWANGer et al. 2003, 2005).

- Small map: The Upper Rhine Graben as main sediment trap of the Rhine between the Alps and the North Sea.

- Large map: Various landsystems along the Rhine from the Alps to the Upper Rhine Graben.

I - Inneralpine (overdeepened) valleys and the ice stream net of the last ice advance.

II - The landsystem of glacial basins and lakes at the alpine margin, including various ice margins and the ice cover of the last ice advance.

III - Hochrhein valley, terraces and buried valleys.

IV - Upper Rhine Graben and the Upper Rhine lowlands, in the southern part mainly sediments of alpine provenance, in the northern part (hatched) mainly sediments of local provenance (Black Forest, Vosges).

$\mathrm{V}$ - The classical pre-alpine meltwater landsystem, type region of the classical glacial units of the Würmian, the Rißian, the Mindelian and the Günzian.

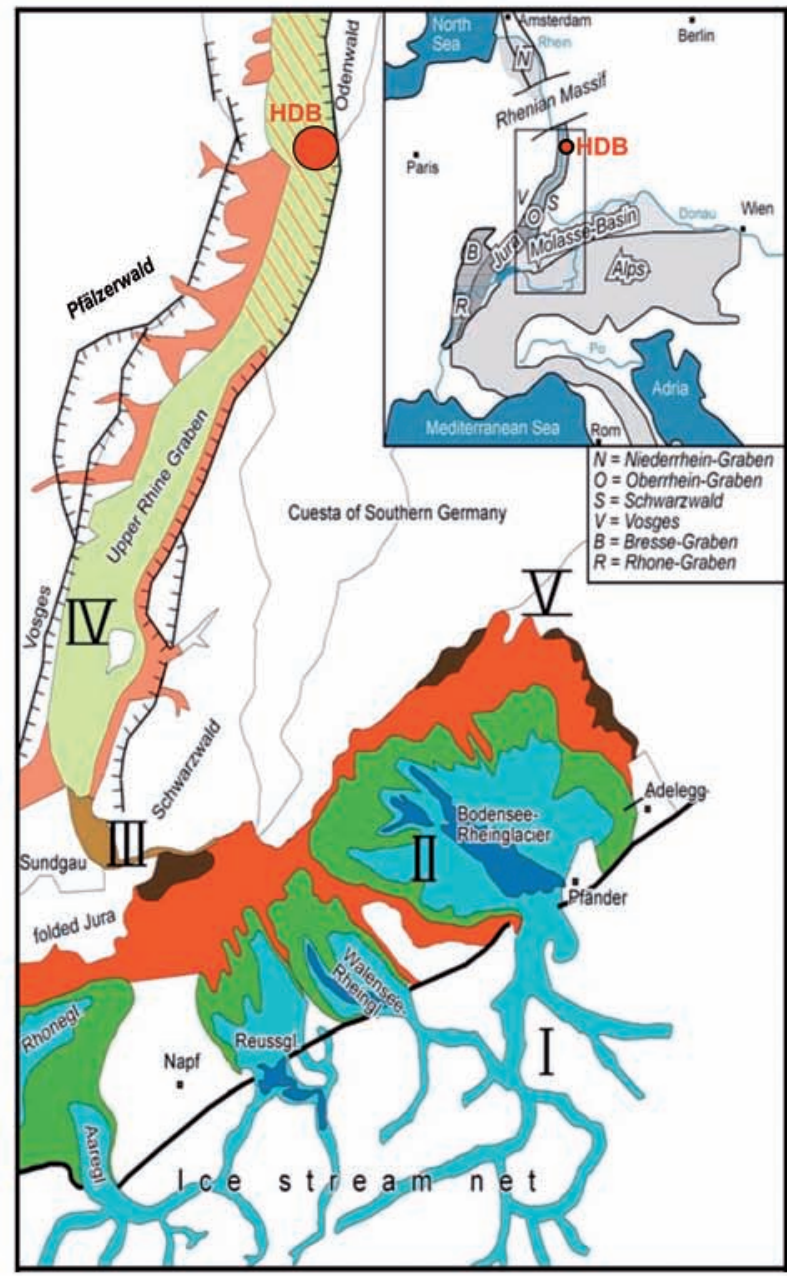

\section{I - inneralpine ice stream net during last ice advance}
II - landsystem of glacial basins at the alpine margin

- covered by ice during the last advance

- Würm-Maximum

- Riss-Maximum

- most extensive ice advance

\section{III - Hochrhein Valley}

IV - Upper Rhine Graben resp. lowlands

- alpine input

- local input

- (hatched) mainly local, but with alpine signals 
Tab. 1: Lithostratigraphic units as introduced by the three Geological Surveys working on the Heidelberg Basin.

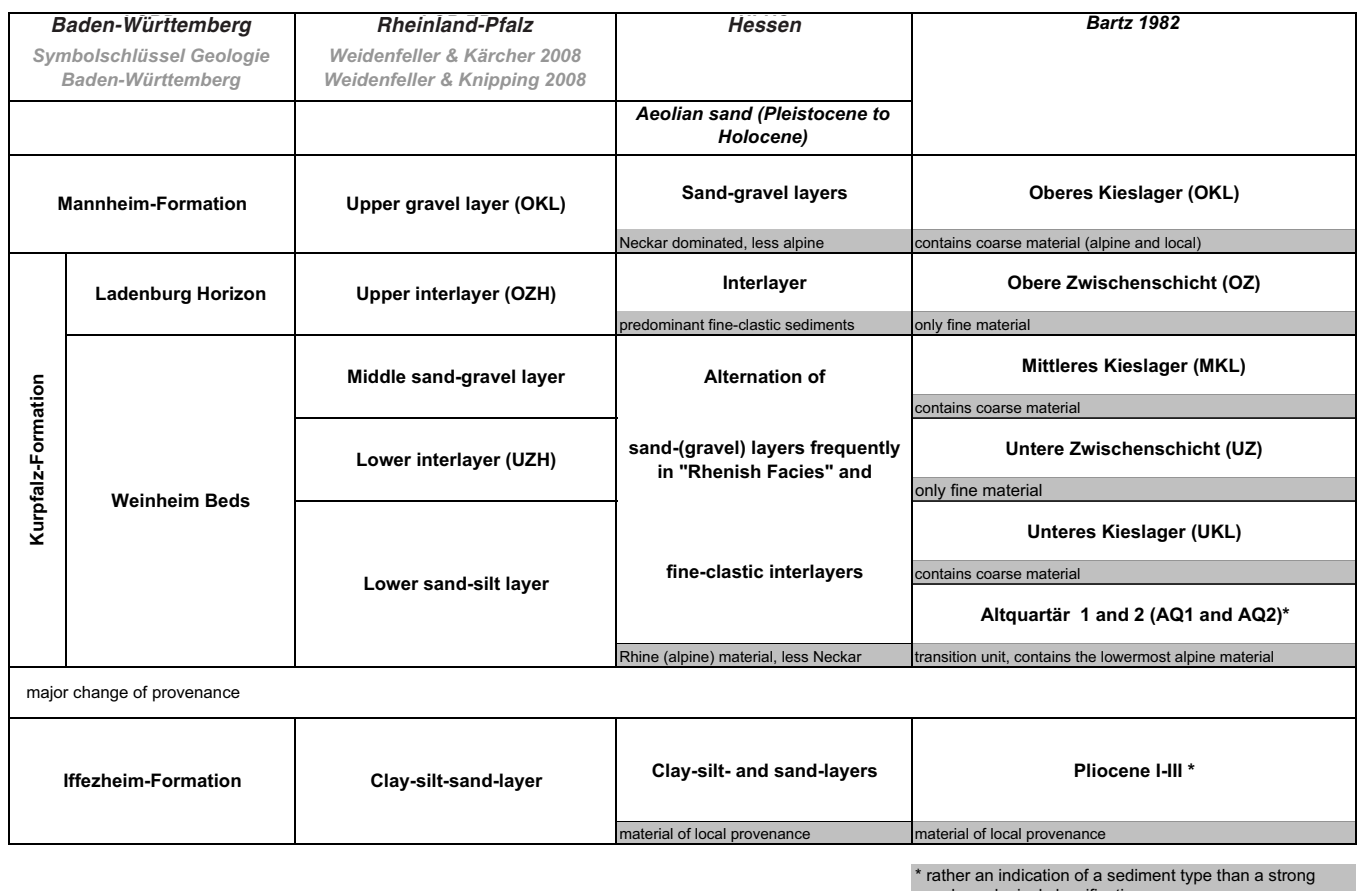

plied Geophysics and the Geological Survey of Baden-Württemberg. Combining all new cored boreholes, $1450 \mathrm{~m}$ of core material is available now for a detailed investigation program.

At present, no uniform classification for the Plio-/Pleistocene deposits is available for the three federal states, that are working on the Heidelberg Basin, namely Baden-Württemberg, Hessen, and Rheinland-Pfalz. Within each Geological Survey some mandatory guidelines exist that match the specific requirements derived from the local geology. The geology of the southern Upper Rhine Graben on the territory of Baden-Württemberg is significantly affected by the deposition of coarse-grained sediments eroded in the Alps. Therefore, a classification was introduced that considers major unconformities and therefore the dynamic of the sedimentary system in the southern Upper Rhine Graben (Symbolschlüssel Geologie BADEN-WÜRTTEMBERG 2007). In contrast, the terminology used in Hessen and RheinlandPfalz is built on the systems introduced by
BARTz (1982) and HGK (1999), which distinguish between hydrogeological units. At this early stage of the Heidelberg Basin project, it is impossible to set up a uniform nomenclature. Table 1 summarizes the different classifications used in this special issue.

To overcome these discrepancies, investigations in the Heidelberg Basin project must preliminary focus on the establishment of a reference profile of the region north of the Alps, including petrographic, sequence stratigraphic, biostratigraphic, and magnetostratigraphic approaches, complemented by geochronological and geophysical data. Beyond these local to regional aspects, these boreholes offer a sediment archive of supra-regional relevance, particularly regarding the correlation between the glacial evolution in the alpine region and that of Northern Europe. In this context, proxies of past environmental / climate change will be also derived. These aims can only be achieved because the drilled cores reveal a high temporal resolution without significant disconformities 


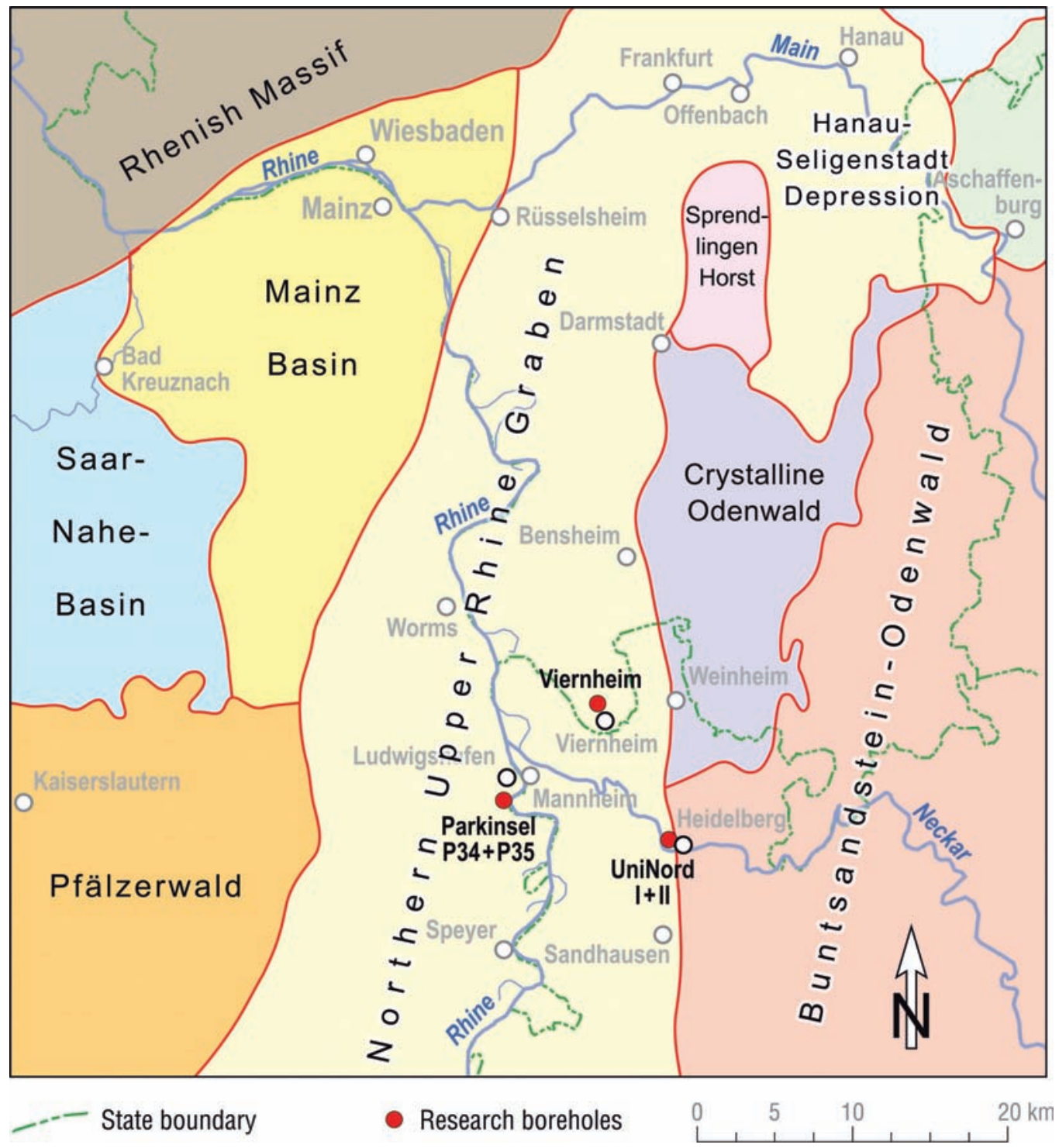

Fig. 2: Geological structural zones with the three borehole locations Ludwigshafen-Parkinsel (cored boreholes P34 and P35, both $300 \mathrm{~m}$ deep), Viernheim (350 m deep), and Heidelberg UniNord (research boreholes Heidelberg UniNord 1, $190 \mathrm{~m}$ deep, and Heidelberg UniNord 2, $500 \mathrm{~m}$ deep) in the Heidelberg Basin. 
(Hoselmann et al. 2008). The papers compiled in this special volume of the Quaternary Science Journal (Eiszeitalter und Gegenwart) prove that the drilled cores can be considered as nearly ideal with respect to these aspects.

Due to the availability of the two boreholes in Ludwigshafen at an early stage in this joint project, a comprehensive dataset already exists for this location. WeIDENFELLER \& KNIPPING (2008) present complementary and consistent datasets as heavy mineral analysis, pollen assemblages and the core description itself. Somewhat surprising the results of the two Ludwigshafen-Parkinsel boreholes differ in some aspects significantly, although the locations lie only $500 \mathrm{~m}$ apart. Whereas the upper sections of both boreholes correlate well, thicknesses of individual layers in the deeper part are quite variable. Even the transition between Pliocene and Pleistocene deposits was found at different depths. Consequently this region seems to be affected by tectonics during Upper Pliocene/ Lower Pleistocene. These results emphasize that the interpretation of the climatic and fluvial history of an area on the basis of the analysis of only a few boreholes becomes very difficult, not only because the sediments were affected by fluvial dynamics, but also by small-scale tectonics. The distinct characterisation and stratigraphic identification based on several independent methods, and on pollen analysis in particular, are basic requirements for a reliable interpretation of the sedimentation history controlled both by climate and tectonics.

Considering the data available so far, a pattern similar to that in Ludwigshafen is found in the Viernheim borehole (Hoselmann 2008). Based on heavy mineral data, carbonate content, and petrography, the transition Plio/Pleistocene is seen at $225 \mathrm{~m}$ depth. However, this boundary is not sharp, but imaged as a transition zone consisting of a reworked horizon. The Pleistocene sediment succession is dominated by alpine sediments, local deposits from the Neckar occur only occasionally. The main part of the Pleistocene section is made up of ten repeated suites that begin with gravely sand layers and end with silty clay sediments or peat. Due to miss- ing pollen data, a detailed correlation with the Ludwigshafen boreholes has not been possible so far. However, Hoselmann (2008) presents a first correlation with other boreholes of the Viernheim-Bensheim region, based on reference markers, e.g. the occurrence of the „Rhenish Facies". Although a general trend of increasing thickness of the Rhenish Facies towards the centre of the Heidelberg Basin in the south is depicted, the fundamental problem of hampered correlation due to the absence of particular beds at some borehole locations is also addressed.

The last of the boreholes to finish was the Heidelberg UniNord at the end of July 2008 (Ellwanger et al. 2008). Based on the information from the reflection seismic surveys and the old Radium Sol Therme borehole, this location was expected to represent the depocentre of the Heidelberg Basin. With respect to the first palynological data, this assumption seems to be confirmed. Even at $420 \mathrm{~m}$ depth Quaternary pollen assemblages are found. If this can be confirmed by more detailed studies in future at this location, the thickness of Pleistocene sediments would be about three times more than in Ludwigshafen; therefore the temporal resolution will be increased by the same amount. Furthermore, the results of the reflection seismic surveys and the pollen data are promising, regarding the completeness of the profile. The interglacials - Cromerian, Bavelian, Waalian, and Tiglian - could already be identified by a first scan of the pollen assemblages. To some extent the cores reveal strong and fast changes of the accommodation space and sediment supply ratio. The mostly-fluviatile character of the depositional environment was temporarily interrupted by lacustrine periods.

To close the gap of seismic information in the centre of the Heidelberg Basin and to ensure that the boreholes reveal thick and more or less complete sediments, geophysical pre-site surveys were conducted at the Viernheim and the Heidelberg borehole locations (Buness, Gabriel \& Ellwanger 2008). In close relation to this project, the first gravity map of the Upper Rhine Graben that comprises all available French and German data was com- 
piled (RotsteIN et al. 2006). This map clearly images the course of the Upper Rhine Graben by the occurrence of negative gravity anomalies, of which the strongest is observed in the area around Heidelberg. This could be an indicator for a sediment succession of unusual large thickness. Furthermore, in the vicinity of the borehole Heidelberg UniNord reflection seismic profiles were recorded of which one N-S profile contributed significantly to the decision about the location for the borehole (BUNESS, GABRIEL \& EllWANGer 2008). This profile imaged for the first time a sub basin within the Heidelberg Ba$\sin$. The usefulness of a seismic pre-site survey was also well demonstrated by the investigations around the borehole in Viernheim. Without the seismic information the borehole would have penetrated a fault at only $200 \mathrm{~m}$ depth - something that should be avoided with regard to the goals of this project. Based on the results of the seismic surveys, the borehole location could be relocated by several hundred meters.

One of the challenges of this project is the correlation between the three locations of the new boreholes, and beyond this, the correlation with additional, shallower boreholes in the area of the Heidelberg Basin. In addition to lithostratigraphic or biostratigraphic approaches results from geophysical downhole logging can also reveal additional insight into the sedimentary system. Downhole logging data is of particular value, wherever core quality is low or - even worse - core is not recovered, because it provides in-situ information about the sediment successions. HunZE \& WONIK (2008) discuss the physical properties of the different lithologies on the basis of logging data and suggest a hole-to-hole correlation between several locations in the Heidelberg Basin. Furthermore, by statistical analysis of specific data sets additional information about sediment provenance could be derived. With sediments deposited by the rivers Rhine and Neckar, two main sediment provenances could be distinguished.

Facing the challenge of stratigraphic correlation, but also that of climate reconstruction, WEDEL (2008) analysed core material from both the Viernheim and Ludwigshafen locations with regard to their fossil content, and particularly the remains of molluscs. The potential for the preservation of molluscs is highly variable. Fossils are often found in the argillaceous layers of the fine-grained horizons (Zwischenhorizonte), and to a minor amount also in the fine and medium-grained sand fraction of the coarse-grained horizons (Kieslager). The Pliocene beds do not contain any significant remnants of molluscs. Especially from a Mid-Pleistocene horizon, distinct information about several interglacials can be revealed that are suitable for correlation with pollen data and a reconstruction of the palaeo-environment. As a highlight, two mollusc species and one rodent species from the Lower Pleistocene (Lower Biharium) were identified in the northern Upper Rhine Graben for the first time.

First pollen spectra from the research borehole Heidelberg UniNord 1 are discussed by HaHNE, Ellwanger \& Stritzke (2008). Although only four short sections with well-preserved pollen were found, with the evidence for a Waalian thermomer, a first biostratigraphic marker of regional relevance was found. The pollen spectrum derived from the peaty sequence between 180 and $181.7 \mathrm{~m}$ depth is very similar to the flora of the type-locality for the Waalian (the Leerdam section in the Netherlands), both in pollen genera and quantities. Especially the occurrence of Tsuga strengthens the interpretation as Waalian. From these first findings a uniform forest vegetation in Mid Europe for the early Pleistocene is concluded, representing a climate that was not warmer than today.

In future, correlation between all the available boreholes must be based on a combination of several independent observations. Beside geophysical data and palynological data, absolute geochronological data is required especially. Unfortunately, no dating method is available that can be applied to the entire Quaternary age spectrum. Young sediments (up to $\sim 150 \mathrm{ka}$ ) can be dated by applying luminescence dating techniques. Although in the meantime some few and unpublished results are available for the new cored-boreholes in the Heidelberg Basin (pers. communication Lauer), the method has been tested before with fluviatile sediments of 
the Bremgarten section in the southern part of the Upper Rhine Graben (FreChEN et al. 2008). The results prove that OSL dating is a suitable method for fluviatile sediments from large river systems. Insufficient bleaching of the sediments prior to deposition seems to be not as dramatic as previously thought. The most important finding for the Bremgarten section is a short period of major erosion and re-sedimentation of fluvial sediments from the "Tiefgestade“ at the Bremgarten section between 500 and 600 years before present, which correlates with the begin of the Little Ice Age ca. AD 1450. Likewise interesting results are expected for the Heidelberg Basin Drilling Project in the future.

This special issue on the Heidelberg Basin Drilling Project is published at an early stage of a just-starting joint research project that comprises aspects from many geoscientific disciplines. The intention of this issue is to make some main results already available to the geoscientific community, e.g. the reflection seismic data or the lithologs of the new-cored boreholes. In fact, detailed analytic investigation of the core material has not begun. Therefore, a uniform interpretation of the three borehole locations cannot be presented, which becomes especially obvious with the use of the terms „Base Quaternary“ or „transition PlioPleistocene“. But the cored boreholes should provide unique material to solve these challenges during the next years. Some aspects of this study have been submitted as a proposal to the German Research Foundation in 2008.

These eight contributions to this special issue of the Quaternary Science Journal (Eiszeitalter und Gegenwart) present the most recent findings from ongoing research on the Heidelberg Basin. Thereby, they complement some papers dealing with „The Rhine - a major fluvial record", which is the title of a special issue of the Netherlands Journal of Geosciences published in 2008, edited by Wim Westerhoff. This special issue addresses, for instance, issues like the tectonic influence on the preservation of fluviatile sediments (Weidenfeller \& KÄrCHER 2008), palynological investigations (KNIPPING 2008), heavy mineral analysis (HAGEDORN \& BoENIGK
2008), and rock and paleomagnetic studies (Rolf, Hambach \& Weidenfeller 2008).

\section{Acknowledgement}

Drilling projects are always challenging tasks, requiring support from many persons and institutions. The Heidelberg Drilling Project profited significantly from the support of actual and former heads of the involved institutions, namely Prof. Dr. U. Yaramanci, Prof. Dr. H.-J. Kümpel, Prof. Dr. R. Watzel, Ltd. Bergdirektor V. Dennert, Prof. Dr. B. Stribrny, Dr. R. Becker, and Prof. Dr. $H$. Ehses. The cores from the Ludwigshafen-Parkinsel boreholes were made available by Technische Werke Ludwigshafen. Logistic support was given by the University of Heidelberg, who provided the piece of land for the Heidelberg UniNord 1 borehole, Helmut Huber and the Amt für Vermögen und Bau Baden-Württemberg, Mannheim, who made the piece of land for the Heidelberg UniNord 2 borehole available, and the Springer publishing group. Dr. E. Würzner, Lord Major of the city of Heidelberg, and Dr. R. Franke, Stadtwerke Viernheim, arranged contacts, whenever necessary. The involved members of staff of the Amt für Umweltschutz Heidelberg and the Universitätsbauamt Heidelberg were always interested in the project and helped in a friendly way wherever they could. All this support is gratefully acknowledged.

Prerequisite for this special issue about the Heidelberg Basin Drilling Project was the offer from Holger Freund as editor of Quaternary Science Journal (Eiszeitalter und Gegenwart) to publish a special issue. He organised the review process with great patience. But the most important work was done by the many authors who contributed with their papers to this issue. The corresponding comments of many reviewers helped to improve these papers. Many thanks to all colleagues involved!

\section{References}

Bartz, J. (1951): Revision des Bohr-Profils der Heidelberger Radium-Sol-Therme. - Jahresberichte und Mitteilungen des Oberrheinischen Geolo- 
gischen Vereins, 33: 101-125.

BARTZ, J. (1982), mit Beitr. von Brelie, G. von der und Maus, H.: Quartär und Jungtertiär II im Oberrheingraben im Großraum Karlsruhe. - Geologisches Jahrbuch, A 63: 3-237.

Buness, H., Gabriel, G. \& Ellwanger, D. (2008): The Heidelberg Basin drilling project: Geophysical pre-site surveys. - Quaternary Science Journal (Eiszeitalter und Gegenwart), 57/3-4: 338-366.

EllWANGER, D. (2003), unter Mitarbeit von Lämmermann-Barthel, J. und Neeb, I.: Eine landschaftsübergreifende Lockergesteinsgliederung vom Alpenrand zum Oberrhein. - GeoArchaeoRhein, 4: 81-124.

Ellwanger, D., Gabriel, G., Hoselmann, C., LämMERMANN-BARThel, J. \& Weidenfeller, M. (2005): The Heidelberg Drilling Project (Upper Rhine Graben, Germany). - Quaternaire, 16/3: 191-199.

Ellwanger, D., Gabriel, G., Simon, T., WielandtSchuster, U., Greiling, R.O., Hagedorn, E.-M., Hahne, J. \& Heinz, J. (2008): Long sequence of Quaternary Rocks in the Heidelberg Basin Depocentre. - Quaternary Science Journal (Eiszeitalter und Gegenwart), 57/3-4: 316-337.

Fezer, F. (1997): $220 \mathrm{~m}$ Altpleistozän im „Heidelberger Loch“. - Eiszeitalter und Gegenwart, 47: 145-153.

Frechen, M., Ellwanger D., Rimkus, D. \& Techmer, A. (2008): Timing of Medieval Fluvial Aggradation at Bremgarten in the Southern Upper Rhine Graben. - Quaternary Science Journal (Eiszeitalter und Gegenwart), 57/3-4: 411-432.

Hagedorn, E. \& Boenigk, W. (2008): The Pliocene and Quaternary sedimentary and fluvial history of the Upper Rhine Graben based on heavy mineral analysis. - Netherlands Journal of Geosciences - Geologie en Mijnbouw, 87/1: 21-32.

Hahne, J., Ellwanger, D. \& Stritzke, R. (2008): Evidence for a Waalian thermomer pollen record from the research borehole Heidelberg UniNord, Upper Rhine Graben, Baden-Württemberg. - Quaternary Science Journal (Eiszeitalter und Gegenwart), 57/3-4: 403-410.

HGK (1999): Hydrogeologische Kartierung und Grundwasserbewirtschaftung Rhein-NeckarRaum. Fortschreibung 1983-1999. - Ministerium für Umwelt und Verkehr Baden-Württemberg, Hessisches Ministerium für Umwelt, Landwirtschaft und Forsten, Ministerium für Umwelt und Forsten Rheinland-Pfalz: 155 p.; Stuttgart, Wiesbaden, Mainz.

Hoselmann, C. (2008): The Pliocene and Pleistocene fluvial evolution in the northern Upper Rhine Graben based on results of the research borehole at Viernheim (Hessen, Germany). - Quaternary Science Journal (Eiszeitalter und Gegenwart), 57/3-4: 286-315.

Hoselmann, C., Ellwanger, D., Gabriel, G., Wedel, J. \& Weidenfeller, M. (2008): Forschungsbohrungen im nördlichen Oberrheingraben (Heidelberger Becken) - Neue Erkenntnisse zur geologischen Entwicklung. - Abhandlungen der Geologischen Bundesanstalt, 62: 95-98.

Hunze, S. \& WoniK, T. (2008): Sediment Input into the Heidelberg Basin as determined from Downhole Logs. - Quaternary Science Journal (Eiszeitalter und Gegenwart), 57/3-4: 367-381.

KnIPPING, M. (2008): Early and Middle Pleistocene pollen assemblages of deep core drillings in the northern Upper Rhine Graben, Germany. - Netherlands Journal of Geosciences - Geologie en Mijnbouw, 87/1: 51-66.

Rolf, C., Hambach, U. \& Weidenfeller, M. (2008): Rock and palaeomagnetic evidence for the PlioPleistocene palaeoclimatic change recorded in the Upper Rhine Graben sediments (core Ludwigshafen-Parkinsel). - Netherlands Journal of Geosciences - Geologie en Mijnbouw, 87/1: 41-50.

Rotstein, Y., Edel, J.-B., Gabriel, G., Boulanger, D., Schaming, M. \& Munschy, M. (2006): Insight into the structure of the Upper Rhine Graben and its basement from a new compilation of Bouguer Gravity. - Tectonophysics, 425/1-4: 55-70.

Salomon, W. (1927) : Die Erbohrung der Heidelberger Radium-Sol-Therme und ihre geologischen Verhältnisse. - Abhandlungen Heidelberger Akademie der Wissenschaften, 14: 1 - 105.

Symbolschlüssel Geologie Baden-Württemberg: Verzeichnis Geologischer Einheiten - Aktualisierte Ausgabe März 2007. - Internet-Publ.: http:// www.lgrb.uni-freiburg.de; Freiburg i. Br. (Reg.Präs. Freiburg - L.-Amt Geol. Rohst. Bergb.).

Wedel, J. (2008): Pleistocene molluscs from research boreholes in the Heidelberg Basin. - Quaternary Science Journal (Eiszeitalter und Gegenwart), 57/3-4: 382-402.

Weidenfeller, M. \& Kärcher, T. (2008): Tectonic influence on fluvial preservation: aspects of the architecture of Middle and Late Pleistocene sediments in the northern Upper Rhine Graben, Germany. - Netherlands Journal of Geosciences - Geologie en Mijnbouw, 87(1): 33-40.

Weidenfeller, M. \& Knipping, M. (2008): Correlation of Pleistocene sediments from boreholes in the Ludwigshafen area, western Heidelberg Basin. - Quaternary Science Journal (Eiszeitalter und Gegenwart), 57/3-4: 270-285. 


\begin{tabular}{|l|l|l|l|}
\hline $\begin{array}{l}\text { Eiszeitalter und Gegenwart } \\
\text { Quaternary Science Journal }\end{array}$ & 57/3-4 & 261-269 & Hannover 2008 \\
\hline
\end{tabular}

\title{
Vorwort: Das Bohrprojekt „Heidelberger Becken“
}

\author{
Gerald Gabriel, Dietrich Ellwanger, Christian Hoselmann \& Michael Weidenfeller
}

Seit dem späten Pliozän / frühen Pleistozän stellt der Rhein als einer der größten europäischen Flüsse das einzige Entwässerungssystem dar, welches die Alpen mit der Nordsee verbindet. Auf seinem Verlauf von den Alpen bis hin zum Ärmelkanal passiert er unterschiedliche geomorphologische und geologische Einheiten, von denen der Oberrheingraben die Hauptsedimentfalle bildet (Abb. 1). Während die alpinen Vorlandbecken aufgrund der hohen Dynamik des Gesamtsystems nur ein geringes Erhaltungspotenzial hinsichtlich der Sedimentablagerung aufweisen, und das Ablagerungsgebiet unmittelbar an der Nordseeküste mehrfach signifikant durch pleistozäne Meeresspiegelschwankungen beeinflusst wurde, bietet die andauernde Subsidenz des Oberrheingrabens einmalige Bedingungen für die kontinuierliche Akkumulation von Sedimenten. Die beiden größten Sedimentfallen sind dabei das Geiswasser Becken im südlichen Teil sowie das Heidelberger Becken im Nordosten. Generell nimmt die mittlere Korngröße der im Oberrheingraben abgelagerten alpinen Sedimente von Süden nach Norden ab. Das Heidelberger Becken fungiert als distale Falle im Oberrheingraben für alpine Sedimente, die durch den Rhein Richtung Norden transportiert werden. Hier ist die kontinuierliche Ablagerung von Sedimenten weniger stark durch Diskontinuitäten gestört als im südlichen Teil des Rheingrabens. Daher stellt das Heidelberger Becken eine Schlüsselposition für das Verständnis der glazialen Entwicklung der Alpen seit dem späten Pliozän und darüber hinaus für einen Vergleich mit der glazialen Entwicklung Nordeuropas dar (ElLWANGER et al. 2005).

Das Heidelberger Becken enthält eine der mächtigsten Abfolgen plio-/pleistozäner Sedimente im kontinentalen Mitteleuropa. Die Ra- dium Sol Therme Bohrung, welche zwischen 1913 und 1918 im Zentrum von Heidelberg abgeteuft wurde, wird in der Literatur bis heute kontrovers diskutiert. Die „Quartärbasis“ wird in Tiefen von $382 \mathrm{~m}$ (BARTZ 1951), $400 \mathrm{~m}$ (SALOMON 1927) oder sogar 650 m (FeZER 1997) gesehen. Durch umfassende reflexionsseismische Messungen ist heute belegt, dass die quartären Ablagerungen Mächtigkeiten größer $300 \mathrm{~m}$ erreichen. Da reflexionsseismische Untersuchungen jedoch nur in der Umgebung von Heidelberg durchgeführt wurden, nicht jedoch im Stadtgebiet selbst, waren bislang keine detaillierten Informationen über quartäre Strukturen in diesem Bereich verfügbar.

Mit dem Ziel, zu einem tieferen Verständnis hinsichtlich der geologischen Entwicklung des Heidelberger Beckens, insbesondere der Steuerung durch Klimaveränderungen und Tektonik, sowie der Korrelation der alpinen und nordeuropäischen Vereisungsgeschichte zu gelangen, wurde das Bohrprojekt „Heidelberger Becken“ durch das Leibniz-Institut für Angewandte Geophysik (LIAG - vormals Institut für Geowissenschaftliche Gemeinschaftsaufgaben, GGAInstitut) und die drei geologischen Dienste von Baden-Württemberg, Hessen und RheinlandPfalz initiiert. Das Projekt fokussiert auf die Beckenentwicklung seit dem späten Pliozän. Die Untersuchungen basieren wesentlich auf neuen Kernbohrungen an drei verschiedenen Lokationen innerhalb des Heidelberger Beckens, welche unterschiedliche Faziesräume abbilden (Abb. 2). Zwei 300 m tiefe Kernbohrungen in Ludwigshafen - abgeteuft 2002 und 2006 - repräsentieren den westlichen Rand des Beckens. Diese Bohrungen wurden im Rahmen der Grundwassererkundung realisiert und dem Geologischen Dienst von Rheinland-Pfalz zur Verfügung gestellt. Die $350 \mathrm{~m}$ tiefe Kernboh- 
Abb. 1: Das Heidelberger Becken (HDB) im Geosystem „Rhein“ (verändert nach ELLWANGER et al. 2003, 2005).

- Kleine Karte: Der Oberrheingraben als Hauptsedimentfalle des Rheins zwischen Alpen und Nordsee.

- Große Karte: Verschiedene Landschaftstypen entlang des Rheins von den Alpen bis zum Oberrheingraben.

I - Inneralpine (übertiefe) Täler und die Eisströme beim letzten Vorstoß.

II - Randalpine Becken- und Seenlandschaft mit verschiedenen Eisrandlagen und der Eisbedeckung beim letzten Vorstoß.

III - Hochrheintal, Terrassenstufen und verschüttete Täler.

IV - Oberrheingraben bzw. oberrheinische Tiefebene, Lockersedimente im Südteil überwiegend alpiner Herkunft, im Nordteil (schräg schraffiert) überwiegend lokaler Herkunft (Schwarzwald, Vogesen).

V - Die klassische oberschwäbische Schmelzwasserterrassenlandschaft (Typregion für Würm, Riss, Mindel und Günz).

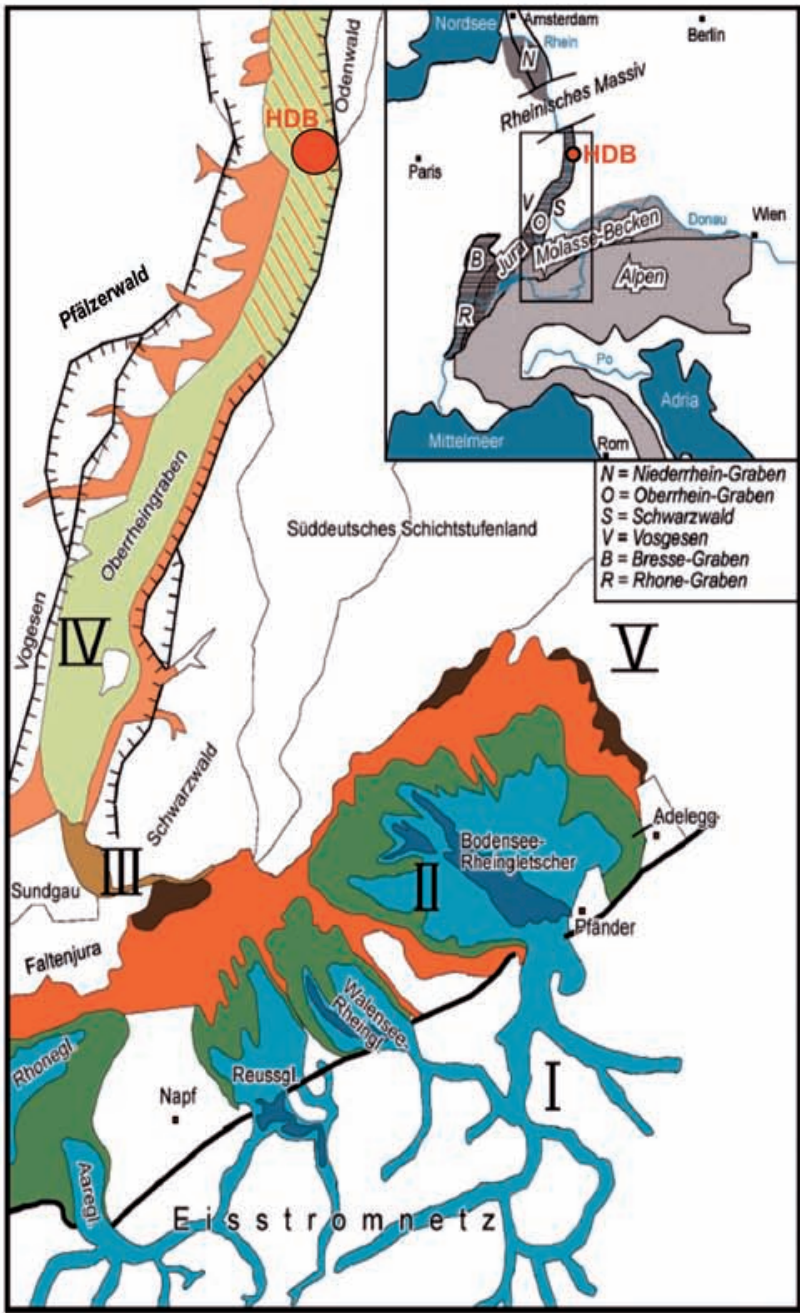

- inneralpine Eisströme beim letzten Vorstoß

\section{II - randalpine Beckenlandschaft}

- Eisbedeckung beim letzten Vorstoß

- Würm-Maximum

- Riss-Maximum

- weitester Vorstoß

III - Hochrheintal

IV - Oberrheingraben bzw. oberrheinische Tiefebene

- alpine Schüttungen

- lokale Schüttungen

- (schräg schraffiert) überwiegend lokal

V - klassische alpine Quartär-Typusregion 
Tab. 1: Lithostratigraphische Einheiten, wie sie durch die drei Geologischen Dienste verwendet werden, welche Anteile am Heidelberger Becken haben.

\begin{tabular}{|c|c|c|c|c|}
\hline \multicolumn{2}{|c|}{$\begin{array}{c}\text { Baden-Württemberg } \\
\text { Symbolschlüssel Geologie } \\
\text { Baden-Württemberg }\end{array}$} & $\begin{array}{c}\text { Rheinland-Pfalz } \\
\text { Weidenfeller \& Kärcher } 2008 \\
\text { Weidenfeller \& Knipping } 2008\end{array}$ & Hessen & Bartz 1982 \\
\hline & & & $\begin{array}{c}\text { Äolische Sande (Pleistozän bis } \\
\text { Holozän) }\end{array}$ & \\
\hline \multirow{2}{*}{\multicolumn{2}{|c|}{ Mannheim-Formation }} & \multirow[t]{2}{*}{ Oberes Kieslager (OKL) } & Sand-Kies Lagen & Oberes Kieslager (OKL) \\
\hline & & & Neckar-dominiert, wenig alpin & Grobsedimente (alpin und lokal) \\
\hline \multirow{10}{*}{ 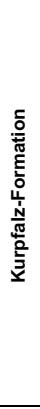 } & \multirow[t]{2}{*}{ Ladenburg Horizont } & \multirow[t]{2}{*}{ Oberer Zwischenhorizont (OZH) } & Zwischenhorizont & Obere Zwischenschicht (OZ) \\
\hline & & & vorwiegend feinklastische Sedimente & nur Feinsedimente \\
\hline & \multirow{8}{*}{ Weinheim Schichten } & \multirow[t]{2}{*}{ Mittlere sandig-kiesige Folge } & \multirow[t]{2}{*}{ Wechsel von } & Mittleres Kieslager (MKL) \\
\hline & & & & Grobsedimente (alpin und lokal) \\
\hline & & \multirow[t]{2}{*}{ Unterer Zwischenhorizont (UZH) } & \multirow[t]{5}{*}{$\begin{array}{l}\text { Sand-(Kies) Lagen häufig in } \\
\text { "Rheinischer Fazies" und }\end{array}$} & Untere Zwischenschicht (UZ) \\
\hline & & & & nur Feinsedimente \\
\hline & & \multirow{4}{*}{ Untere sandig-siltige Folge } & & Unteres Kieslager (UKL) \\
\hline & & & & Grobsedimente (alpin und lokal) \\
\hline & & & & Altquartär 1 und 2 (AQ1 und AQ2)* \\
\hline & & & (alpine) Rheinsedimente, wenig Neckar & Übergangsbereich mit ersten alpinen Sedimenten \\
\hline \multicolumn{5}{|c|}{ Wechsel des Hauptliefergebietes } \\
\hline \multirow{2}{*}{\multicolumn{2}{|c|}{ Iffezheim-Formation }} & \multirow[t]{2}{*}{ Ton-Sand-Silt Folgen } & Ton-Silt und Sand Lagen & Pliozän I-III * \\
\hline & & & Sedimente lokalen Ursprungs & Sedimente lokalen Ursprungs \\
\hline
\end{tabular}

rung bei Viernheim soll Informationen über die zentrale Beckenfazies liefern. Diese im Sommer 2006 abgeschlossene Bohrung wurde durch den Geologischen Dienst von Hessen betreut und finanziert. Die letzte Kernbohrung, Heidelberg UniNord, wurde im Subsidenzzentrum des Beckens am östlichen Rand des Oberrheingrabens angesetzt. Diese durch das Leibniz-Institut für Angewandte Geophysik und den Geologischen Dienst von Baden-Württemberg finanzierte Bohrung hat ihre Endteufe von $500 \mathrm{~m}$ im Juli 2008 erreicht. Alle neuen Kernbohrungen zusammen liefern $1450 \mathrm{~m}$ Kernmaterial, das nun für ein detailliertes Untersuchungsprogramm zur Verfügung steht.

Bislang existiert in den Bundesländern mit Anteilen am Heidelberger Becken (BadenWürttemberg, Hessen und Rheinland-Pfalz) keine einheitliche Gliederung der plio-/ pleistozänen Ablagerungen. In jedem geologischen Dienst gibt es verbindliche Vorgaben, welche den spezifischen Gegebenheiten der lokalen Geologie Rechnung tragen. Die Geologie des südlichen Oberrheingrabens in Baden-Württemberg wird maßgeblich durch die Ablagerung grobklastischer Sedimente bestimmt, die in den Alpen abgetragen wurden. Daher wird eine Formationsgliederung angewendet, die im südlichen Graben die Hauptdiskontinuitäten und somit die Dynamik des Systems berücksichtigt (SYMBOLSCHLÜSSEL Geologie Baden-Württemberg 2007). Dagegen basiert die in Hessen und Rheinland-Pfalz verwendete Terminologie zum Teil auf den von BARTZ (1982) und durch die HGK (1999) eingeführten Systemen, die zwischen hydrogeologischen Einheiten unterscheiden. In diesem frühen Stadium des Projekts „Heidelberger Becken" ist die Definition einer einheitlichen Nomenklatur noch nicht möglich. Tabelle 1 stellt die in diesem Themenheft verwendeten unterschiedlichen Gliederungen gegenüber. Um diese Diskrepanzen zu überwinden, müssen die Untersuchungen im Projekt „Heidelberger 


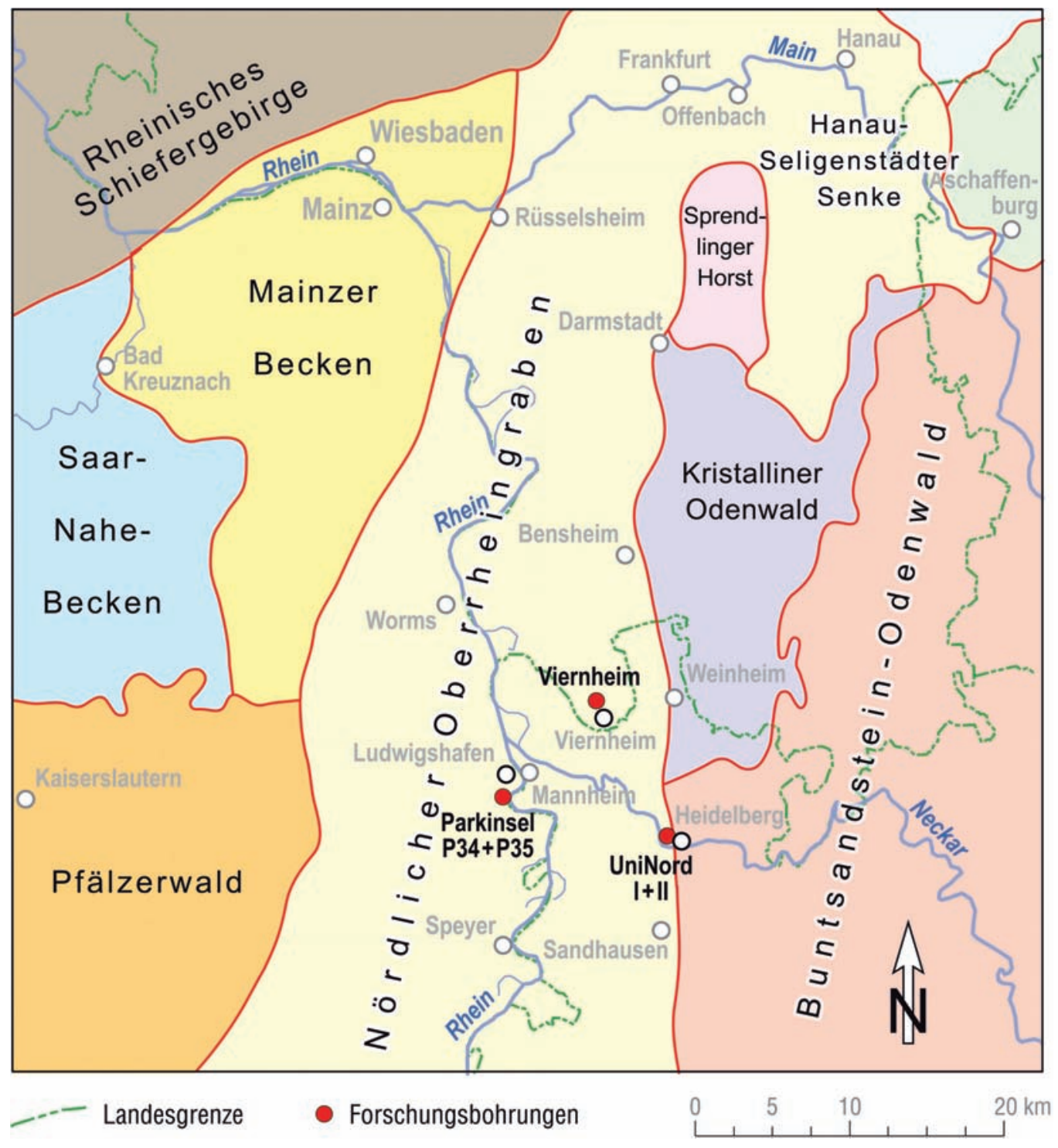

Abb. 2: Geologische Strukturräume mit den drei Bohrlokationen Ludwigshafen-Parkinsel (Kernbohrungen P34 und P35, jeweils $300 \mathrm{~m}$ tief), Viernheim (350 m tief) und Heidelberg UniNord (Forschungsbohrungen Heidelberg UniNord 1, $190 \mathrm{~m}$ tief und Heidelberg UniNord 2, $500 \mathrm{~m}$ tief) im Heidelberger Becken. 
Becken“ zunächst auf die Erstellung eines Referenzprofils für das Gebiet nördlich der Alpen ausgerichtet sein. Dieses beinhaltet petrographische, sequenzstratigraphische, biostratigraphische und magnetostratigraphische Ansätze, die durch geochronologische und geophysikalische Daten ergänzt werden. Über diese lokalen bis regionalen Aspekte hinaus ist mit den neuen Bohrungen im Hinblick auf die Korrelation der glazialen Entwicklungen im Alpenraum und Nordeuropa ein Sedimentarchiv von überregionaler Bedeutung erschlossen worden. In diesem Zusammenhang sollen auch Proxy für Umweltveränderungen/Klimaveränderungen in der Vergangenheit abgeleitet werden. Diese Ziele können nur erreicht werden, weil die gebohrten Kerne eine hohe zeitliche Auflösung und nur wenige Schichtlücken aufweisen (Hoselmann et al. 2008). Die in diesem Themenheft vom Quaternary Science Journal (Eiszeitalter und Gegenwart) zusammengestellten Artikel zeigen, dass die gebohrten Kerne unter diesen Aspekten als nahezu ideal angesehen werden können.

Aufgrund der Verfügbarkeit der beiden Kernbohrungen in Ludwigshafen zu einem sehr frühen Zeitpunkt in diesem Projekt, liegt für diese Lokation aktuell der umfangreichste Datensatz vor. Weidenfeller \& KNIPPING (2008) präsentieren sich ergänzende konsistente Datensätze von Schwermineralanalysen, Pollenanalysen und der Kernbeschreibung selbst. Etwas überraschend unterscheiden sich die Ergebnisse der beiden Bohrungen Ludwigshafen-Parkinsel P34 und P35 in einzelnen Aspekten signifikant, obwohl beide Lokationen nur etwa $500 \mathrm{~m}$ auseinander liegen. Während die oberen Abschnitte beider Bohrungen gut korrelieren, sind die Mächtigkeiten einzelner Einheiten des unteren Teils lateral sehr variabel. Selbst der Übergang Plio-/Pleistozän wurde in unterschiedlichen Teufen angetroffen. Folglich erscheint diese Region während des späten Pliozäns/frühen Pleistozäns maßgeblich durch Tektonik beansprucht worden zu sein. Diese Ergebnisse belegen, dass die Ableitung der klimatischen und fluviatilen Entwicklung einer Region un- sicher ist, sofern diese nur auf einer Bohrung beruht. Die Sedimente werden nicht nur durch die fluviatile Dynamik beeinflusst, sondern auch durch kleinmaßstäbliche tektonische Ereignisse. Die auf verschiedenen unabhängigen Untersuchungen, insbesondere auch Pollenanalysen, basierende Charakterisierung und stratigraphische Einordnung der Sedimente ist grundlegende Voraussetzung für eine verlässliche Interpretation der durch Klima und Tektonik gesteuerten Ablagerungsgeschichte. Unter Berücksichtigung des bislang vorliegenden Datensatzes ergibt sich für die Bohrung Viernheim ein Bild, das dem in Ludwigshafen sehr ähnlich ist (Hoselmann 2008). Auf Schwermineralanalysen, Karbonatgehalten und der Petrographie basierend, wird der Übergang Plio/Pleistozän bei $225 \mathrm{~m}$ gesehen. Allerdings handelt es sich dabei um keinen scharfen Übergang, sondern um einen Bereich aufgearbeiteter Horizonte. Die pleistozäne Sedimentabfolge wird durch alpines Material dominiert, lokale Ablagerungen des Neckars treten nur untergeordnet auf. Der wesentliche Teil des pleistozänen Abschnitts wird aus zehn sich wiederholenden Abfolgen aufgebaut, welche mit kiesig-sandigen Lagen beginnen und mit schluffig-tonigen Sedimenten enden. Aufgrund noch fehlender Pollenanalysen kann bislang keine detaillierte Korrelation mit den Bohrungen in Ludwigshafen vorgenommen werden. Jedoch stellt HoSELMANN (2008) basierend auf Leithorizonten, wie dem ersten Auftreten der „Rheinischen Fazies“, erste Korrelationen mit weiteren Bohrungen aus der Region Viernheim-Bensheim vor. Wenngleich der generelle Trend einer $\mathrm{Zu}$ nahme der Mächtigkeit der rheinischen Fazies zum Zentrum des Heidelberger Beckens hin aufgezeigt werden kann, wird auch das fundamentale Problem der erschwerten Korrelation infolge an bestimmten Lokationen fehlender einzelner Schichtpakete angesprochen.

Die Heidelberg UniNord Bohrung wurde erst Ende Juli 2008 fertig gestellt (Ellwanger et al. 2008). Basierend auf den Ergebnissen der reflexionsseismischen Erkundung und der alten Bohrung Radium Sol Therme wird davon ausgegangen, dass diese Lokation das Depozent- 
rum des Heidelberger Beckens repräsentiert. Diese Annahme scheint durch die ersten palynologischen Daten bestätigt zu werden. Selbst in $420 \mathrm{~m}$ Teufe ist das Pollenspektrum noch quartärzeitlich. Sollte sich dieses Ergebnis zukünftig durch detaillierte Untersuchungen erhärten, wäre die Mächtigkeit der pleistozänen Sedimente an dieser Lokation etwa dreifach so groß wie in Ludwigshafen und es würde sich die erwartete hohe zeitliche Auflösung bestätigen. Darüber hinaus werden die Ergebnisse der reflexionsseismischen Messungen und der Pollendaten als viel versprechend im Hinblick auf die Vollständigkeit des Profils angesehen. Bereits bei der ersten Durchsicht der Pollenspektren konnten die Interglaziale Cromer, Bavel, Waal und Tiglium identifiziert werden. Die Bohrkerne zeigen teilweise starke und auch schnelle Änderungen im Verhältnis von Akkommodationsraum zu Sedimentangebot. Der meist fluviatil geprägte Ablagerungsraum wird zeitweise von lakustrinen Perioden abgelöst. Um die Lücke an seismischen Informationen im Zentrum des Heidelberger Beckens zu schließen und sicher zu stellen, dass die Bohrungen mächtige und vergleichsweise vollständige Sedimente erschließen, wurden an den Bohrlokationen Viernheim und Heidelberg UniNord geophysikalische Vorerkundungen durchgeführt (Buness, Gabriel \& Ellwanger 2008). In enger Verknüpfung mit diesem Projekt wurde die erste Schwerekarte des Oberrheingrabens erstellt, die sämtliche verfügbaren Daten von französischer und deutscher Seite berücksichtigt (Rotstein et al. 2006). Diese Karte bildet durch das Auftreten negativer Schwereanomalien deutlich den Verlauf des Oberrheingrabens $a b$, von denen die größte im Bereich um Heidelberg zu beobachten ist. Dies kann als Hinweis auf Sedimentabfolgen von ungewöhnlich großer Mächtigkeit angesehen werden. Ferner wurden im Umfeld der Bohrung Heidelberg UniNord reflexionsseismische Profile aufgenommen, von denen ein N-S Profil maßgeblich zur Festlegung des Bohrpunktes beigetragen hat (Buness, Gabriel \& Ellwanger 2008). Dieses Profil bildet zum ersten Mal ein Subbecken im Heidelberger Becken ab. Der Mehr- wert einer seismischen Vorerkundung wurde ebenfalls durch die Untersuchungen rund um die Bohrlokation bei Viernheim demonstriert. Ohne die seismischen Informationen hätte die Bohrung bereits in einer Tiefe von $200 \mathrm{~m}$ eine Störung durchteuft - ein Sachverhalt, der im Hinblick auf die Ziele dieses Projekts unbedingt vermieden werden sollte. Die Ergebnisse der seismischen Messungen berücksichtigend konnte der Bohransatzpunkt somit um einige hundert Meter verschoben werden.

Eine der Herausforderungen in diesem Projekt liegt sicherlich in der Korrelation zwischen den drei Lokationen der neuen Bohrungen sowie darüber hinaus in der Korrelation mit weiteren, weniger tiefen Bohrungen im Bereich des Heidelberger Beckens. In Ergänzung zu lithostratigraphischen oder biostratigraphischen Ansätzen können auch bohrlochgeophysikalische Messungen Einblicke in das sedimentäre System liefern. Bohrlochgeophysikalische Daten sind dort von besonderem Wert, wo die Kernqualität schlecht ist, oder - noch ungünstiger - keine Kerne gewonnen werden konnten, da sie in-situ Informationen über die Sedimentabfolgen zur Verfügung stellen. HunzE \& WoNIK (2008) diskutieren die physikalischen Eigenschaften der verschiedenen Lithologien auf der Basis von Bohrlochmessungen und schlagen eine Korrelation zwischen verschiedenen Bohrpunkten im Heidelberger Becken vor. Darüber hinaus werden durch die Anwendung statistischer Verfahren auf spezifische Datensätze Informationen bezüglich der Liefergebiete der Sedimente abgeleitet. Mit Sedimentablagerungen durch den Rhein bzw. den Neckar können zwei unterschiedliche Liefergebiete unterschieden werden.

Ebenfalls die stratigraphische Korrelation betreffend, aber auch Aspekte der Paläo-Klimarekonstruktion, analysiert WEDEL (2008) Kernmaterial der Bohrungen Viernheim und Ludwigshafen unter paläontologischen Aspekten, insbesondere im Hinblick auf Molluskenreste. Das Erhaltungspotenzial für Mollusken erscheint hochgradig variabel. Fossilien werden oftmals in den lehmig/tonigen Schichten der feinkörnigen Lagen (Zwischenhorizonte) 
gefunden, untergeordnet auch in den feinen und mittelfeinen Sanden der grobkörnigen Ablagerungen (Kieslager). In den pliozänen Ablagerungen finden sich keinerlei Molluskenreste. Eindeutige Informationen über mehrere Interglaziale können insbesondere aus einem Horizont entnommen werden, welcher dem mittleren Pleistozän zugeordnet wird. Diese Daten sind sowohl für die Korrelation mit Pollenanalysen als auch für die Rekonstruktion der Paläo-Umweltbedingungen geeignet. Ein „Highlight“ stellt der erstmalige Fund von zwei Molluskenarten sowie einer Nagetierart im nördlichen Oberrheingraben aus dem unteren Pleistozän (Unteres Biharium) dar.

Hahne, Ellwanger \& Stritzke (2008) diskutieren erste Pollenanalysen der Forschungsbohrung Heidelberg UniNord 1. Wenngleich gut erhaltene Pollen lediglich in vier kurzen Abschnitten aufgefunden wurden, konnte mit der Identifikation der Waal-Warmzeit ein biostratigraphischer Marker bestimmt werden, der auch überregional von Bedeutung ist. Das der torfigen Sequenz zwischen 180,0 und 181,7 m zugehörige Pollenspektrum ähnelt sowohl hinsichtlich der Pollentypen als auch der Pollenhäufigkeit stark der Flora des Typus-Profils für das Waalium (Profil Leerdam, Niederlande). Insbesondere das Auftreten von Tsuga bedingt die Einordnung in die Waal-Warmzeit. Basierend auf diesen ersten Ergebnissen wird eine einheitliche Bewaldung Mitteleuropas im Zeitraum des frühen Pleistozäns postuliert, die ein Klima repräsentiert, das nicht wärmer war als das heutige.

Korrelationen zwischen den verschiedenen Bohrungen müssen zukünftig auf der Kombination der verschiedenen unabhängigen Verfahren aufbauen. Neben geophysikalischen und palynologischen Daten sind vor allem absolute Altersdatierungen notwendig. Leider steht kein Datierungsverfahren zur Verfügung, welches auf das gesamte Quartär angewendet werden kann. Junge Sedimente (bis zu $\sim 150 \mathrm{ka}$ ) können mit Lumineszenztechniken datiert werden. Obwohl inzwischen auch erste unpublizierte Ergebnisse für die neuen Kernbohrungen im Heidelberger Becken vorliegen (Lauer, pers.
Mitteilung), wurde die Methode zunächst an fluviatilen Sedimenten des Profils Bremgarten aus dem südlichen Teil des Oberrheingrabens getestet (FreChen et al. 2008). Die Ergebnisse zeigen, dass OSL-Techniken für die Datierung fluviatiler Sedimente großer Flusssysteme geeignet sind. Eine ungenügende Bleichung der Sedimente vor der Ablagerung scheint weniger großen Einfluss auf die Ergebnisse zu haben, wie bislang angenommen. Das wesentliche Ergebnis hinsichtlich des Profils Bremgarten besteht in der Ermittlung eines kurzen Abschnitts starker Erosion und Resedimentation fluviatiler Sedimente des Tiefegestades vor 500 bis 600 Jahren. Dieses Ereignis korreliert mit dem Beginn der kleinen Vereisung etwa 1450 AD. Ähnlich interessante Datierungsergebnisse sind zukünftig im Rahmen des Bohrprojektes „Heidelberger Becken" zu erwarten.

Dieses Themenheft über das Heidelberger Becken erscheint zu einem frühen Zeitpunkt eines gerade beginnenden Forschungsvorhabens, welches Aspekte diverser geowissenschaftlicher Disziplinen vereint. Die Intention besteht darin, verschiedene grundlegende Ergebnisse, wie die Daten der Reflexionsseismik oder die Lithologs der neuen Kernbohrungen, der geowissenschaftlich arbeitenden Gemeinschaft verfügbar zu machen. Tatsächlich fehlen noch verschiedene detaillierte Untersuchungen am Kernmaterial. Daher kann zum jetzigen Zeitpunkt keine gemeinsame Interpretation des gesamten Kernmaterials vorgestellt werden, was sich insbesondere in der unterschiedlichen Verwendung der Begriffe "Quartärbasis“ oder „Übergang Plio-/Pleistozän“ niederschlägt. Mit den neuen Bohrkernen sollte aber einzigartiges Material zur Verfügung stehen, um diese Aufgabe in den kommenden Jahren lösen zu können. Ein Teil der Untersuchungen soll im Rahmen eines Antragpakets durchgeführt werden, welches 2008 bei der Deutschen Forschungsgemeinschaft eingereicht wurde.

Die acht Beiträge zu diesem Themenheft des Quaternary Science Journal (Eiszeitalter und Gegenwart) präsentieren die aktuellsten Ergebnisse andauernder Forschungsarbeiten zum Heidelberger Becken. Damit komplettieren 
sie verschiedene Artikel, welche sich mit dem „Rhein - ein bedeutendes fluviatiles Sediment-

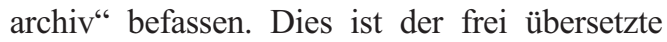
Titel eines Sonderbands des Netherlands Journal of Geosciences, der 2008 unter der Editorenschaft von Wim Westerhoff publiziert wurde. Dieser Sonderband spricht ergänzende Themen, wie den Einfluss der Tektonik auf die Erhaltung fluviatiler Sedimente (WEIDENFELLER \& KÄRCHER 2008), palynologische Untersuchungen (KNIPPING 2008), Schwermineralanalysen (HAGEDORN $\&$ BoENIGK 2008) sowie gesteins- und paläomagnetische Studien (Rolf, Hambach \& WeidenFELLER 2008) im Oberrheingraben an.

\section{Dank}

Bohrprojekte stellen stets eine herausfordernde Aufgabe dar, die Unterstützung vieler Personen und Institutionen verlangt. Das Bohrprojekt „Heidelberger Becken“ hat wesentlich von der Unterstützung der derzeitigen und früheren Leiter der beteiligten Einrichtungen profitiert, namentlich Prof. Dr. U. Yaramanci, Prof. Dr. H.-J. Kümpel, Prof. Dr. R. Watzel, Ltd. Bergdirektor V. Dennert, Prof. Dr. B. Stribrny, Dr. R. Becker und Prof. Dr. H. Ehses. Die Kernbohrungen Ludwigshafen-Parkinsel wurden durch die Technischen Werke Ludwigshafen zur Verfügung gestellt. Logistische Unterstützung gaben die Universität Heidelberg in Form der Bereitstellung des Grundstücks für die Bohrung Heidelberg UniNord 1, Helmut Huber sowie das Amt für Vermögen und Bau Baden-Württemberg mit der Bereitstellung des Geländes für die Bohrung Heidelberg UniNord 2 und der Springer-Verlag. Dr. E. Würzner, Oberbürgermeister der Stadt Heidelberg, und Dr. R. Franke, Stadtwerke Viernheim, vermittelten Kontakte, wo immer notwendig. Die beteiligten Mitarbeiter des Amts für Umweltschutz der Stadt Heidelberg und der Universität Heidelberg waren stets am Fortgang des Projekts interessiert und gaben jegliche Hilfe, die notwendig war. Für die gesamte Unterstützung herzlichen Dank!

Voraussetzung für dieses Themenheft über das Bohrprojekt „Heidelberger Becken“ war das Angebot von PD Dr. H. Freund als Editor von Quaternary Science Journal (Eiszeitalter und Gegenwart) einen Sonderband zu publizieren. Er organisierte mit großer Geduld das Begutachtungsverfahren. Die wichtigsten Arbeiten wurden jedoch durch die vielen Autoren durchgeführt, die mit ihren Artikeln zu diesem Themenheft beitragen. Die Anmerkungen der Gutachter gaben wesentliche Hinweise für die Verbesserung einzelner Manuskripte. Vielen Dank an alle Kollegen, die sich beteiligt haben!

\section{Literatur}

BARTZ, J. (1951): Revision des Bohr-Profils der Heidelberger Radium-Sol-Therme. - Jahresberichte und Mitteilungen des Oberrheinischen Geologischen Vereins, 33: 101-125.

Bartz, J. (1982), mit Beitr. von Brelie, G. von der und Maus, H.: Quartär und Jungtertiär II im Oberrheingraben im Großraum Karlsruhe. - Geologisches Jahrbuch, A 63: 3-237.

Buness, H., Gabriel, G. \& Ellwanger, D. (2008): The Heidelberg Basin drilling project: Geophysical pre-site surveys. - Quaternary Science Journal (Eiszeitalter und Gegenwart), 57/3-4: 338-366.

Ellwanger, D. (2003), unter Mitarbeit von Lämmermann-Barthel, J. und Neeb, I.: Eine landschaftsübergreifende Lockergesteinsgliederung vom Alpenrand zum Oberrhein. - GeoArchaeoRhein, 4: 81-124.

Ellwanger, D., Gabriel, G., Hoselmann, C., LÄMmERMAnN-BARThel, J. \& Weidenfeller, M. (2005): The Heidelberg Drilling Project (Upper Rhine Graben, Germany). - Quaternaire, 16/3: 191-199.

Ellwanger, D., Gabriel, G., Simon, T., WielandtSchuster, U., Greiling, R.O., Hagedorn, E.-M., Hahne, J. \& Heinz, J. (2008): Long sequence of Quaternary Rocks in the Heidelberg Basin Depocentre. - Quaternary Science Journal (Eiszeitalter und Gegenwart), 57/3-4: 316-337.

FEzer, F. (1997): 220 m Altpleistozän im „Heidelberger Loch". - Eiszeitalter und Gegenwart, 47: 145-153.

Frechen, M., Ellwanger D., Rimkus, D. \& Techmer, A. (2008): Timing of Medieval Fluvial Aggradation at Bremgarten in the Southern Upper Rhine Graben. - Quaternary Science Journal (Eiszeitalter und Gegenwart), 57/3-4: 411-432. 
Hagedorn, E. \& Boenigk, W. (2008): The Pliocene and Quaternary sedimentary and fluvial history of the Upper Rhine Graben based on heavy mineral analysis. - Netherlands Journal of Geosciences - Geologie en Mijnbouw, 87/1: 21-32.

Hahne, J., Ellwanger, D. \& Stritzke, R. (2008): Evidence for a Waalian thermomer pollen record from the research borehole Heidelberg UniNord, Upper Rhine Graben, Baden-Württemberg. - Quaternary Science Journal (Eiszeitalter und Gegenwart), 57/3-4:403-410.

HGK (1999): Hydrogeologische Kartierung und Grundwasserbewirtschaftung Rhein-NeckarRaum. Fortschreibung 1983-1999. - Ministerium für Umwelt und Verkehr Baden-Württemberg, Hessisches Ministerium für Umwelt, Landwirtschaft und Forsten, Ministerium für Umwelt und Forsten Rheinland-Pfalz: 155 p.; Stuttgart, Wiesbaden, Mainz.

Hoselmann, C. (2008): The Pliocene and Pleistocene fluvial evolution in the northern Upper Rhine Graben based on results of the research borehole at Viernheim (Hessen, Germany). - Quaternary Science Journal (Eiszeitalter und Gegenwart), 57/3-4: 286-315.

Hoselmann, C., Ellwanger, D., Gabriel, G., Wedel, J. \& Weidenfeller, M. (2008): Forschungsbohrungen im nördlichen Oberrheingraben (Heidelberger Becken) - Neue Erkenntnisse zur geologischen Entwicklung. - Abhandlungen der Geologischen Bundesanstalt, 62: 95-98.

Hunze, S. \& Wonik, T. (2008): Sediment Input into the Heidelberg Basin as determined from Downhole Logs. - Quaternary Science Journal (Eiszeitalter und Gegenwart), 57/3-4: 367-381.

KNIPPING, M. (2008): Early and Middle Pleistocene pollen assemblages of deep core drillings in the northern Upper Rhine Graben, Germany. - Netherlands Journal of Geosciences - Geologie en Mijnbouw, 87/1: 51-66.
Rolf, C., Hambach, U. \& Weidenfeller, M. (2008): Rock and palaeomagnetic evidence for the PlioPleistocene palaeoclimatic change recorded in the Upper Rhine Graben sediments (core Ludwigshafen-Parkinsel). - Netherlands Journal of Geosciences - Geologie en Mijnbouw, 87/1: 41-50.

Rotstein, Y., Edel, J.-B., Gabriel, G., Boulanger, D., Schaming, M. \& Munschy, M. (2006): Insight into the structure of the Upper Rhine Graben and its basement from a new compilation of Bouguer Gravity. - Tectonophysics, 425/1-4: 55-70.

Salomon, W. (1927) : Die Erbohrung der Heidelberger Radium-Sol-Therme und ihre geologischen Verhältnisse. - Abhandlungen Heidelberger Akademie der Wissenschaften, 14: 1-105.

Symbolschlüssel Geologie Baden-Württemberg: Verzeichnis Geologischer Einheiten - Aktualisierte Ausgabe März 2007. - Internet-Publ.: http://www.lgrb.uni-freiburg.de; Freiburg i. Br. (Reg.-Präs. Freiburg - L.-Amt Geol. Rohst. Bergb.).

Wedel, J. (2008): Pleistocene molluscs from research boreholes in the Heidelberg Basin. - Quaternary Science Journal (Eiszeitalter und Gegenwart), 57/3-4: 382-402.

Weidenfeller, M. \& Kärcher, T. (2008): Tectonic influence on fluvial preservation: aspects of the architecture of Middle and Late Pleistocene sediments in the northern Upper Rhine Graben, Germany. - Netherlands Journal of Geosciences - Geologie en Mijnbouw, 87/1: 33-40.

Weidenfeller, M. \& KNIPPING, M. (2008): Correlation of Pleistocene sediments from boreholes in the Ludwigshafen area, western Heidelberg Basin. - Quaternary Science Journal (Eiszeitalter und Gegenwart), 57/3-4: 270-285. 